\title{
THE EFFECT OF PAY \\ AND ADMINISTRATIVE CONTROL \\ ON ETHICAL BEHAVIOUR \\ IN THE NIGERIAN PUBLIC SERVICE
}

\section{Okechukwu Ikeanyibe}

Ph.D.

Department of Public Administration \& Local

Government University of Nigeria, Nsukka.

E-mail: Okey.ikeanyibe@unn.edu

\section{Jide lbietan}

Ph.D., Associate Professor (Public Administration)

Department of Political Science \& International Relations

Covenant University, Ota, Ogun State, Nigeria.

E-mail: Olajide.ibietan@covenantuniversity.edu.ng

\begin{abstract}
This study investigates the effects of pay vis-à-vis elements of the ethics infrastructure that contribute to effective administrative control; and to unethical practices in the Nigerian public service. Based on critical analysis of primary official and secondary data, the study reveals that corruption and financial impropriety are far more common and intense among higher public officials who, incidentally, are better remunerated, than among the lower cadre officials, who are poorly remunerated. The study shows that despite the emphasis on the compliance or sanction approach to administrative ethics rather than the virtue approach, there is still wide incongruence between the ethical approach adopted and the expected results. This is because of the existence of a weak political and administrative control system at the higher administrative functions. The study suggests that reducing unethical practices should aim at improving openness and transparency at the high level through more citizen involvement and civil society action, reviewing the criminal justice system to ensure severe punishment that can serve the purpose of deterrence and prevention, speedy dispatch of corruption cases and strengthening of oversight linkages between the public institutions and ethics coordinating institutions.
\end{abstract}

Keywords: Administrative ethics, pay; administrative control; ethics infrastructure; Nigerian public service.

Citation: Ikeanyibe, O. \& Ibietan, J. (2018). The Effect of Pay and Administrative Control on Ethical Behaviour in the Nigerian Public Service. Public Administration Issues, Special Issue II (electronic edition), pp. 24-44 (in English); DOI: 10.17323/1999-5431-2018-0-6-24-44 


\section{Introduction}

Employees' remuneration, or pay, is a major variable for evaluating their organizational behaviour. Since the time of Frederick Taylor and the scientific managers, the consideration of pay as a motivation for employee performance has generally attracted support in the literature. Financial rewards have the capacity to maintain and motivate individuals towards higher performance (Dobre, 2013). On the other hand, it can also fail to boost productivity and improve performance significantly (Whitley, 2002). These dual characteristics of pay as a motivator can also be extended to the examination of issues of unethical financial practices such as fraud, bribe taking and other self-enriching practices of public officials. The question can be asked as to whether employee pay or remuneration determines the level of unethical financial practices in a public service system. Scholars like Rose-Ackerman (1999) have posited that if public sector pay is very low, corruption tends to be a survival strategy. Van Rijckeghem and Weder (1997) show that relative high wages of public servants are associated with lower corruption. Similarly, Dmochowski, Jurczuk and Szczepankowski (n.d.) aver that public service conditions, may be more or less conducive to ethical behavior by public servants. Thus, low pay in the public sector may be blamed for the prevalence of corruption and other unethical practices especially in low-income countries. Adedokun (2016) avers that any country intent on seriously fighting corruption must pay public servants fair and realistic wages benchmarked to private sector earnings.

While the above observations cannot be ignored, it appears, however that this cannot be a unilateral and one dimensional relationship as in the case of pay and motivation. Low pay does not constitute a necessary and sufficient condition for unethical financial behaviour of public officials. A number of other components have been found to equally determine the ethical behaviour of workers. The Organization for Economic Cooperation and Development (OECD) has, since 1996, evolved the notion of ethics infrastructure. The ethics infrastructure is a range of tools and processes to regulate undesirable behaviour and to provide incentives for good conduct among workers. Following surveys and analyses of approaches adopted by member countries on how public servants can be given support in observing the highest standards of integrity and ethics in the public sector environment, the OECD Public Management Committee (PUMA) underscored eight vital elements that constitute a holistic and comprehensive strategy in determining factors influencing ethical behaviour in the public service of OECD countries. A cursory look at the components of the OECD ethics infrastructure reveals that these are also measures applied by other countries in an effort to deal with issues of ethics and corruption. They include: political commitment, effective legal framework, efficient accountability mechanisms and workable codes of conduct, professional socialization mechanisms (including training), supportive public service conditions, existence of a central ethics coordinating body and an active civil society able to act as a watchdog over the actions of officials.

The divergence in the ethical statuses of countries apparently depends on the degree of efficiency and effectiveness in institutionalizing the ethics infrastructure. The OECD survey (1996) also reveals that countries embark on some permutations 
in establishing the ethics infrastructure. Invariably, countries pay more attention to some of the elements in relation to their ethics climate (Stare \& Klun, 2016). It is in this vein that this study seeks to evaluate the relative importance of the elements in determining the level of ethical success or failure in the Nigerian public service system. The questions that the research seeks to answer include: what factors promote unethical practices in the Nigerian public service? How does the component of pay contrast with administrative control measures in relation to the low and high level public officials in this challenge? Specifically, the study investigates and compares the level of pay among the higher and lower cadre public officials as well as the effectiveness and comprehensiveness of administrative control at the two levels. Findings show that poor administrative control plays a more significant role in supporting unethical behaviour in the Nigerian public service than pay. The study therefore suggests that reducing unethical practices should aim at ensuring that the topmost layers of the public organisations are effectively checked and controlled.

\section{The Nature of Administrative Ethics}

The importance of ethical consideration in politics or as a social phenomenon dates back to the time of Greek philosophers who were concerned with life in the polis - the Greek city states. Some of the notable Greek Philosophers like Plato and Aristotle regarded ethics as a part of politics, the main function of which was to provide the conditions under which the members of the human community, the polity, would be able to achieve lasting happiness (Makrydemetres, 2002). The central discussion about politics was the question of virtue or vice, goodness or badness, and rightness or wrongness of human actions. Primarily, ethics is a branch of philosophy that tries to logically establish the basis or standard for human action, whether as applicable to oneself or to the society. Thus, ethics can basically be distinguished into personal and social ethics; personal ethics being applicable to the individual person while social ethics concerns itself with groups (Lynch \& Lynch, 2006). The intrinsic connection between the two aspects lies in the fact that social actions are carried out by individuals. Thus, no matter how we perceive countries, societies, groups or their organisations and institutions as legal personalities, their actions are ultimately reducible to that of individuals or at least a collection of individuals. This therefore raises the question of fiduciary and moral responsibility on the individual, about how his actions should benefit or disadvantage the society. This of course has not obfuscated the fact that ethics is also about the good life of the individual, which may or may not synchronize with the 'social' goal. Life is personal and the good life could be evaluated using different and often contradicting standards. Hence, ethics as a concept is "open to conflicting interpretations' (Martinez, 2008, p. 15). While it may be objectively determined using some agreed universally valued standards such as "honesty, respect for others, trustworthiness" (Denhardt, n.d.), for some, it could as well be subjective and relative.

The challenge of setting a framework for ethical standard is less complicated for social ethics to which administrative ethics could be classified, because it is usual to assume certain common goals of a social group than it is to define what the good life is for individuals. In other words, for group or social ethics such as 
administrative ethics, it is easier to define standards in terms of law, codes, customs and traditions or even guides, rules and regulations. Social ethics embraces a set of norms, assessments and opinions, which are characteristic of a group of people. It points to society, citizens, groups of people as creators of norms and standards of behavior (Dmochowski, Jurczuk \& Szczepankowski, n.d.). This is why Martinez (2008, p. 15) sees law as a concept developed by governments to ensure that citizens engage in 'right conduct.' For him, "the western legal system is grounded on public rules, known and knowable beforehand, governing the manner in which persons within a regime act in conducting public transactions."

It is not just the western legal system but legalisms in every form (natural, social, organizational) which have the objective of determining the basis for right conduct of a group. For this reason, we find that the ethical standards that apply to social positions (e.g. public officials, doctors, lawyers, military personnel, and clergy) reflect the roles and relationships common to that position (Denhardt, n.d.). As a social concern therefore, ethics can be considered as a disposition to act right or wrongly in line with the wishes and benefits of a society. It is in this sense that one can talk of standards of professional conduct or standards of religious conduct, standards of medical practice, standards of the scholarship professional practices, standards of administrative practice, and standards of Christian or Muslim behaviour (Asobie, 2001). Social ethics demands that subscribing to membership of a group or accessing a position necessitates that one should subject oneself to the ethical codes of such group, in spite of his or her own personal ethical standards. This does not justify the adequacy or correctness of social ethical standards understood in terms of law in comparison to individual moral standards. But social, group or organizational life demands compromises of values one holds dear. Social ethical standard requires one to "work within the system as far as basic decency will allow" (Rohr, 1989, p. 11). Where the basic decency is not allowed, the individual reserves that moral right of resignation in protest or resignation on grounds of conscience (Weisband \& Frank, 1975) rather than violate the law.

The point here is that there are two broad conceptual traditions in administrative ethics - the moralist and the instrumentalist traditions. The moralist school tends toward institutional reform, through law and other regulatory mechanisms, while the instrumentalist is more likely to focus on design and enhancement of problem-solving capacities (O'Kelly \& Dubnik, 2012). UNDP (2007) describes the approaches required by these traditions to maintain ethical public service as compliance-based and integrity-based ethics management approaches. Anello (2006, p. 3) sees them as strategies towards effective ethics administration in the public service. Using unethical behaviour of corruption as example, he avers:

Efforts to address the issue of corruption in the public sector have focused on the application of two basic strategies. One strategy has been a legislative reform approach, which establishes laws against corruption with appropriate punitive consequences for violations. This approach is often referred to as the "discipline approach", which attempts to deter corrupt practices through the fear of punishment. The second strategy, often termed the "values approach", attempts to increase institutional integrity by promoting moral values and ethical principles as a way of motivating public servants to behave ethically. 
The discipline approach is compliance-based and focuses on strict compliance with descriptive administrative procedures, control mechanisms and detailed rules which define what public servants should avoid, what they should do, and how they should do it. The value approach, which is discussed also as the virtue ethics in literature (Frankena, 1973; Cooper, 1987), on the other hand entails promoting moral values and ethical principles and making the public officials imbibe them as personal ethical values. It is integrity-based and "encourages good behaviour rather than policing and punishing errors and wrongdoing" (OECD, 2000, p. 25). According to Cooper (1987, p. 321), it concerns '"predispositions' or 'inclinations', traditionally called virtues, which move an administrator to act upon principle, even in the face of anticipated resistance or punishment." Unlike the discipline approach, the virtue approach lacks clear definition of what should be standard behaviour. It involves cognitive activity.

An important issue about the two aspects of administrative ethics discussed above is whether countries should pay more attention to either. Debate on the preeminence of both is not very pronounced in literature. However, a number of scholars, for example, Anello, (2006), UNDP (2007) and Demmke and Moilanen, (2011) have implicitly accorded relative importance to the virtue approach. Anello (2006) agrees that the two approaches cannot be used in isolation. He therefore gives equal importance to the two strategies and argues that neither is sufficient if used alone, but coordinated use of both or a mixed approach is required to have a significant impact on establishing ethical practices within an institution. Underscoring the importance of the two strategies also, Demmke and Moilanen $(2011$, p. 7) consider that the virtue approach is more comprehensive in covering all areas of human actions, arguing that:

Ethical laws, principles and standards do not cover all areas of human actions, nor do they always help in dealing with ethical dilemmas and personal conflicts. This also suggests that ethically good or acceptable behaviour can be defined not only by focusing on obedience to rules but encompasses also such issues like justice and fairness, leadership, ethical culture and the broader social context of behaviour.

Cooper (1987, p. 323) supports this position by positing that virtuous conduct does not amount to merely conditioned reflect behaviour as would law; it is not just unthinking habitual response to stimuli; even though the term 'habit' is sometimes used to characterize virtues, one might say that reason is employed in addressing particular situations, but with a certain pre-established attitude and a conditioned will (Cooper, 1987, p. 323). Rohr (1989) tends to support this view, since for him, administrative discretion is the foundation of administrative ethics. Hence, an official requires a habitual sense of justice and virtue to interpret the mind of law. Nevertheless, Rohr also believes that a government employee should 'work within the system' (obey the law) even at occasional risk to his soul. He therefore believes that the most important ethical infrastructure for the public official or the bureaucrat on whom his work is restrictively focused is the formal, legal or institutional controls. But to the extent that these "are either non-existent or ineffective, bureaucrats have the ethical obligation to respond to the values of the people in whose name they govern. The values in question are not popular whims of the moment, but rather constitutional or regime values. This is because the bureaucrat has taken an oath to uphold the Constitution" (Rohr, 1989, pp. 4-5). Rohr perceives that "all forms of 
organizational life demand compromises of values one holds dear. The person who is unwilling to 'risk his soul occasionally like the rest of us' cannot contribute constructively to any organization" (Rohr, 1989, p. 10).

For some scholars, it is the ethical environment or climate that should determine which of the approaches should command more importance. The compliancebased approach seems more appropriate to situations in which unethical behaviour is rampant and will be difficult to change, while the integrity-based approach appears more appropriate to situations in which there is a strong shared sense of values, and a higher degree of homogeneity (UNDP, 2007). Ethical climate can be defined as the perception of what constitutes right behaviour and thus becomes a psychological mechanism through which ethical issues are managed (Martin \& Cullen 2006, p. 177). In a weak ethical environment such as Nigeria, stealing government resources for instance appears to be heroic. People only aspire to government positions to get rich and indeed one will be considered foolish and stupid by his people to remain poor after holding an exalted public office. In this kind of environment, it is obvious that the political will and even the psychological disposition of officials to do what is universally acceptable as ethical may not be achieved through the value approach or poor attitude to formal, legal or institutional controls. In such an environment where unethical behaviour has reached a crisis, where people tend to retain positions despite obvious ethical scandals, and where corrupt individuals are celebrated and honoured, there is little doubt that finding ways to strengthen the disciplinary approach to administrative ethics will be the way to go. Working to change such a permissive ethical climate will likely be more successful by enacting and enforcing codes of ethics, policies, and directives that specify, discourage, monitor, and correct unethical behavior. In this vein, the disciplinary approach should not be seen only in the mere establishment of what constitutes administrative ethics (law, rules and regulations, codes), but in the manner of enforcement of sanctions against bad conduct. It entails effective administrative control, transparency and accountability in governance. Laws and ethical codes without committed enforcement 'lacks teeth' (Geuras \& Garofalo, 2011, p. 5) as a measure to fight unethical behaviour.

\section{The Nature of Ethics Infrastructure}

Scholars and institutions concerned with administrative ethics have expanded the two strategies to administrative ethics to showcase specific elements usually referred to as ethics infrastructure, which countries have employed to pursue ethics in their public service. The Public Management Committee (PUMA) of the Organization for Economic Cooperation and Development (OECD, 2000) has, through a 1999 survey, identified important elements that OECD countries generally use to promote integrity and prevent unethical conduct in the public service. The elements constitute a framework that has popularly been referred to as ethics infrastructure. While the framework was specifically used by PUMA to provide comparative information about OECD countries, there is a close-fit of the framework to what other countries use in their concern to maintain well-functioning institutions and systems for promoting ethics in their public service. These elements are encapsulated in the table below. 


\section{OECD Ethics Infrastructure}

\begin{tabular}{|c|c|}
\hline $\begin{array}{l}\text { Political } \\
\text { commitment: }\end{array}$ & $\begin{array}{l}\text { Governmental policies and programmes that do not receive support from the } \\
\text { highest political and administrative levels will likely fail. In the absence of } \\
\text { sustained political commitment to ethical behaviour in the administration, efforts } \\
\text { to encourage such behaviour will be in vain }\end{array}$ \\
\hline $\begin{array}{l}\text { Workable codes } \\
\text { of conduct: }\end{array}$ & Codes of conduct play a vital role in stating the expected standards of behaviour \\
\hline $\begin{array}{l}\text { Professional } \\
\text { socialisation } \\
\text { mechanisms: }\end{array}$ & $\begin{array}{l}\text { Socialisation mechanisms are the processes by which public servants learn and } \\
\text { adopt ethical norms, standards of conduct, and public service values. Training } \\
\text { (induction and ongoing) is an essential element to raise ethics awareness and } \\
\text { develop skills capable of solving ethical dilemmas; good role models (especially } \\
\text { managers) also serve this purpose. The content of the codes of conduct or } \\
\text { even legal provisions remains simply words on paper, if it is not adequately } \\
\text { communicated and inculcated }\end{array}$ \\
\hline $\begin{array}{l}\text { Ethics } \\
\text { coordinating } \\
\text { body: }\end{array}$ & $\begin{array}{l}\text { These take various forms - parliamentary committees, central agencies, or } \\
\text { specially created bodies - and assume various functions: "general promoter" of } \\
\text { public sector ethics. The existence of a coordinating body should not be construed } \\
\text { as absolving departments and managers of the responsibility for ensuring ethical } \\
\text { conduct within their jurisdictions }\end{array}$ \\
\hline $\begin{array}{l}\text { Supportive } \\
\text { public service } \\
\text { conditions: }\end{array}$ & $\begin{array}{l}\text { The high standards of ethical conduct expected of public officials are one side } \\
\text { of the coin. The other side is a "package" which provides decent working and } \\
\text { living conditions for the "servants of the public". This "package" consists of } \\
\text { such basic elements as sufficient job security, opportunities for promotion and } \\
\text { career development, fair remuneration or social appreciation. Fair and impartial } \\
\text { human resources management policies can ensure that selection and promotion } \\
\text { processes in the public sector are based on general professional requirements } \\
\text { and non-discrimination, and that other factors, such as, for example, political } \\
\text { considerations, are minimised. If public servants are feeling underpaid, over- } \\
\text { worked and insecure, then they are less likely to embrace initiatives to improve } \\
\text { performance including in the ethical domain }\end{array}$ \\
\hline $\begin{array}{l}\text { Effective legal } \\
\text { framework: }\end{array}$ & $\begin{array}{l}\text { The legal framework is the "teeth" of the overall ethics infrastructure. Laws and } \\
\text { regulations define the basic standards of behaviour for public servants and enforce } \\
\text { them through systems of investigation and prosecution. In reviewing its legal } \\
\text { framework, a country must check that existing criminal codes and civil service } \\
\text { laws, conflict of interest statutes and other regulations which apply to public } \\
\text { servants are clear and consistent }\end{array}$ \\
\hline $\begin{array}{l}\text { Efficient } \\
\text { accountability } \\
\text { mechanisms: }\end{array}$ & $\begin{array}{l}\text { Accountability mechanisms should encourage ethical behaviour by making } \\
\text { unethical activities hard to commit and easy to detect. Accountability mechanisms } \\
\text { set guidelines for government activities, for checking that results have been } \\
\text { achieved, and for checking that due process has been observed. They include } \\
\text { internal administrative procedures (requirements that activities or requests be } \\
\text { recorded in writing), comprehensive processes such as audits and evaluations of } \\
\text { an agency's performance, or new forms of procedures such as whistle-blowing } \\
\text { (which can encourage public servants to expose wrongdoing committed by } \\
\text { others or to say no when asked to do something inappropriate). They might also } \\
\text { be external to the public service: for example, oversight mechanisms such as } \\
\text { legislative or parliamentary committees }\end{array}$ \\
\hline $\begin{array}{l}\text { Active civil } \\
\text { society: }\end{array}$ & $\begin{array}{l}\text { Ethics is everybody's responsibility, including that of an assertive media, which } \\
\text { through its probing reporting helps citizens to act as watchdog over the actions } \\
\text { of public officials. Freedom of information laws guarantee citizen access to public } \\
\text { information from the late } 1960 \text { s and they can institutionalize and support public } \\
\text { awareness and responsiveness }\end{array}$ \\
\hline
\end{tabular}

Source: Adapted from OECD (2000, pp. 24-25). 
It is not generally agreed how to classify these elements in relation to the discipline and virtue approaches. Anello (2006) provides a slightly different ethics infrastructure whose components are:

- A framework of moral values and ethical principles

- A code of conduct

- A programme for the socialization of an ethical framework and code of conduct

- Established anti-corruption legislation

- Established administrative procedures

- Mechanisms for whistle-blowing (ombudsman)

- Sanctions on reprehensible acts

- Mechanisms for collaboration between existing anti-corruption agencies

- Management, coordination and evaluation of an ethical infrastructure

These find corresponding elements in the OECD ethics infrastructure above. Anello (2006) classifies the first three components of his ethics infrastructure as based on the values approach and the remaining six on the disciplinary approach.

In our inclination to argue that the disciplinary approach should be more effective in a permissive ethical environment, coupled with the factor that Nigeria attempts to legislate every possible features of the infrastructure as we shall see briefly, we consider seven of the OECD ethics infrastructure as relevant for the disciplinary strategy. Only the element of supportive public service conditions is used here as the virtue approach whereby good pay for public officials is perceived as helping to reduce moral culpability. This element is explained in (OECD, 2000, pp. 24-25) thus:

The high standards of ethical conduct expected of public officials are one side of the coin. The other side is a "package" which provides decent working and living conditions for the "servants of the public". This "package" consists of such basic elements as sufficient job security, opportunities for promotion and career development, fair remuneration or social appreciation. Fair and impartial human resources management policies can ensure that selection and promotion processes in the public sector are based on general professional requirements and non-discrimination, and that other factors, such as, for example, political considerations, are minimised. If public servants are feeling underpaid, over-worked and insecure, then they are less likely to embrace initiatives to improve performance including the ethical domain.

In this study, all the features of this element are operationalized in terms of relative pay of the higher and lower officials. For further clarification, higher public officials are understood here as political officials that oversee the public institutions and the higher career officials of the directorate rank. These are officials that head units, sections, departments or an entire Ministry, Department or Agency (MDA). The rest of the rank and file in public organizations are considered lower officials.

The OECD (2000) makes another classification of the ethics infrastructure that is also very apt. It employs a three functional classification of Guidance, 
Management and Control to underscore the expected role of each element of the ethics infrastructure in promoting administrative ethics. This classification not only takes care of the legalistic/sanction and value/incentive roles suggested by Anello (2006), but additionally underscores the critical relevance of organizational roles such as leadership and management in providing the necessary coordination required for ethics in public service. Guidance is provided by strong commitment from political leadership; statements of values such as codes of conduct; and professional socialisation activities such as education and training. Management can be realised through co-ordination by a special body or an existing central management agency, and through public service conditions, management policies and practices. Control is assured primarily through a legal framework enabling independent investigation and prosecution; effective accountability and control mechanisms; transparency, public involvement and scrutiny (OECD, 2000, p. 23).

Apparently, where leadership and management are morally weak, control will obviously be weak as well. Provision of incentives and sanctions in themselves are not sufficient to engender ethical behaviour without efforts to guide, lead and control public officials. Control is not just the issue of having laws and sanctions, codes of behaviour and so on, but the commitment to enforce these in the interest of the public trust. It is argued that no amount of sanctions existing in a public service system can ensure effective ethical behaviour where the drive does not originate from the leadership. This is why a former Chief Justice of the Massachusetts Supreme Judicial Court, Edward Hennessey, declared that ethics must begin at the top of an organisation. It is a leadership issue and the chief executive must set an example (Butts and Rich, 2008). Indeed, leadership unites the two aspects of administrative ethics since it is the leader that should be responsible for the enforcement of sanctions and compliance-based ethical systems as well as motivate subordinates to ethical behaviour through values approach. Butts and Rich (2008, pp. 141-142) aver that:

Substantively, leaders can use their power in a positive way to influence people through role modeling... thus using a virtue ethics approach.... Structurally, ethical leadership involves a strategic planning process so that policies, decision-making processes, consultation, accountability and ethical standards, and ongoing assessment and monitoring are in place to ensure ethical practice by the leader and followers. Ethical leadership has a structural component and a substantive character component.

In all, administrative ethics are effective through a process of laws and sanctions, as well as incentive and support system that improve the moral will and rationality of employees to act rightly in the face of an ethical dilemma. The challenge to administrative ethics in most countries including Nigeria is therefore not in the absence of sanctions or incentives but in the commitment and subjection of leadership and management to administrative control, enforcement of sanctions and role modeling. The clear divergence in ethical status of countries is determined by the attention paid to the components of existing ethics infrastructure rather than how beautifully the codes sound. 


\section{Ethical Role of Pay Structure in the}

\section{Nigerian Public Service}

There exists wide salary disparity between the political and career officials in the Nigerian public service in favour of the political officials. The remuneration of political officials in Nigeria has always been couched in secrecy. Indeed, at some point, political leaders unilaterally fixed their salaries themselves. For instance, after the birth of the Second Republic in 1979, the first duty performed by the National Assembly was to fix their salary and allowances which was so high that it irked the Nigerian Labour Congress to demand a salary increase (Adejokun, n.d.). Though the 1999 constitution has assigned the duty of fixing the remuneration of public officials to the Revenue Mobilization Allocation and Fiscal Commission (RMAFC), nothing seems to have changed about the arbitrariness and impunity with which this is done. RMAFC believes in fixing reasonable packages for political officials in a bid to discourage stealing and minimize incidences of corruption in public offices (Ibid.). But it is surprising why this principle does not also count regarding fixing the salaries of career employees.

What is baffling is that Nigerian political officials are known to be among the highest paid in the world in spite of the fact that the country is one of the poorest in the world. In his analysis of the Nigerian Export-Import Bank Economic Confidential Report, Adejokun (n.d.) observes that political office holders in the executive and legislature, including judicial officers totaling 1,268 with the federal government earn a combined pay of NGN173.6 billion. While 4,418 individuals functioning in the same category in the 36 states earned a combined NGN360.091 billion, and 11,788 officers in the 774 local governments earned NGN592.8 billion. The above figures add up to NGN1.126 trillion as pay for 17,474 political office holders in country of 175 million people with a total budget of about NGN5 trillion. As a matter of fact, the Remuneration Act of 2008 pegs the annual salary of a Senator at NGN8.2 million, and a Member of the House of Representatives at NGN4.2 million. This is generally believed not to be exclusive. Other allowances have been estimated to be tenfold of the salary. Allowances and the perks of office usually account far more than the salary (Daily Trust, 2015).

In the face of this gross abuse, the minimum wage for an average Nigerian civil servant is NGN18,000 for the federal civil servant, and significantly less for the states and local government' employees. Efforts to improve the remuneration of public servants over the years usually face enormous challenges including inflation and low financial capacity of the government. In a pay reform carried out by the administration under President Olusegun Obasanjo in 2004, the Salaries, Wages and Emolument Relativity Panel (Prof. E. C. Edozien Panel 2004-2006), and the Presidential Committee on the Consolidation of Emoluments in the Public Sector (Chief Ernest Shonekan Panel, 2006) recommendations led to the introduction of the monetization policy. The policy had sought to establish some coherence in the wide disparity in salaries and allowances among various groups in the public service. Through the reforms, a total of thirteen categories of salary 
structures were recognised through the various stages of implementation of the monetization policy. The table below shows the minimum and maximum emoluments and their compression ratios for various cadres of consolidated salary structures in the federal service.

Table 2

\section{Consolidated Salary Structure of the Nigerian Federal Civil Service}

\begin{tabular}{|c|l|c|c|c|}
\hline S/No. & \multicolumn{1}{|c|}{$\begin{array}{c}\text { Salary } \\
\text { Structure }\end{array}$} & $\begin{array}{c}\text { Lowest Pay } \\
\text { (Per Annum), NGN }\end{array}$ & $\begin{array}{c}\text { Highest Pay } \\
\text { (Per Annum), NGN }\end{array}$ & $\begin{array}{c}\text { Compression } \\
\text { Ratio }\end{array}$ \\
\hline 1 & CONPSS & 226,800 & $5,452,136$ & $1: 24$ \\
\hline 2 & CONTISS II & 303,850 & $5,316,520$ & $1: 4.73$ \\
\hline 3 & CONUASS II & $1,274,177$ & $6,030,963$ & $1: 17.5$ \\
\hline 4 & CONRAISS & 303,850 & $5,316,520$ & $1: 5$ \\
\hline 5 & CONPCASS & $1,084,017$ & $5,407,503$ & $1: 17.5$ \\
\hline 6 & CONTEDISS & 303,850 & $5,316,520$ & $1: 19.18$ \\
\hline 7 & CONMESS & $1,316,488$ & $5,139,000$ & $1: 12.86$ \\
\hline 8 & CONHESS & 267,870 & $5,139,000$ & $1: 12.86$ \\
\hline 9 & CONPASS & 517,020 & $6,647,581$ & $1: 13.72$ \\
\hline 10 & CONPOSS & 517,020 & $6,647,581$ & $1: 14.61$ \\
\hline 11 & CONAFSS & 592,953 & 8,134745 & $1: 2.64$ \\
\hline 12 & CONICSS & 603,917 & $8,825,764$ & \\
\hline 13 & CONTOPSAL & $5,265,701$ & & $13,880,666$ \\
\hline
\end{tabular}

Source: Egbule (2015, p. 11).

From the above table, it can be observed that enormous pay disparity still exists not only among the lowest and highest paid officials, but also among the various consolidated pay categories in the service. Nevertheless, one clear fact is that the salary of those who are supposed to oversee and control the administrative hierarchy (high administrative officials) are in good standing to discourage what Van Rijckeghem and Weder (1997) regard as temptation for corruption. The Consolidated Public Service Salary Structure (CONPSS), that is, the structure for the career core civil service, constitutional bodies, National Assembly Staff, Judiciary Staff and some Parastatals, shows that the annual emolument for the lowest employee is NGN226, 800 and the highest paid civil servant is NGN5, 452,136. The compression ratio is $1: 24$, implying that the highest paid civil servant earns twenty four times more than the lowest paid officials. In others words, the lowest paid staff earns a mere 4.12 per cent of the salary of the highest paid official. With this scenario, if pay determines ethical behaviour, it is expected that unethical financial practices should be higher among the lower paid officials than among political and high administrative public officials. 


\section{Factors that Enhance Unethical Financial Behaviour} in the Nigerian Public Service

Nigeria is undoubtedly ranked as one of the most corrupt countries in the world. She is ranked 136 out of the 175 countries in the 2016 Transparency International Corruption Perception Index (CPI). The Nigerian media are daily awash with reported cases of corruption among public officials. David Cameron, the previous British Prime Minister, described Nigeria as fantastically corrupt. Indeed by his own estimate, Nigeria and Afghanistan could be the two most corrupt countries in the world (Vanguard, 2016). Cameron could not have been speaking from mere imagination as his position as the British Prime Minister, and the negotiation of the two countries about repatriation of stolen funds stashed by Nigerian politicians in British banks should equip him with reasonable information concerning the value of money laundered by Nigerian public officials to foreign banks.

Of course, the reality of high level corruption is irrespective of the various efforts made to prevent it. The country would usually be among the first to subscribe to international conventions and treaties about corruption fighting and ethics in public administration, or locally initiated programmes in this regard. The Udoji Public Service Reform Committee in 1974 (Ikeanyibe, 2010) recommended the introduction of the code of conduct for public officials. This was eventually recognised in the 1979 constitution. Since then, the Code of Conduct Bureau (CCB) has maintained a permanence in subsequent constitutions including the present 1999 constitution (as amended). The Code of Conduct for Public Officers listed in the Fifth Schedule of the 1999 Constitution as amended, Part 1, paragraphs 1 to 14 provides some important ethical codes that could help promote ethical behaviour if judiciously enforced. Provisions include:

- Conflict of Interest: A public officer shall not put himself in a position where his personal interest conflicts with his duties and responsibilities.

- Prohibition of Foreign Accounts: The President, Vice President, Governor, Deputy Governor, Ministers of the Government of the federation and Commissioners of the Governments of the States, members of the National Assembly and the Houses of Assembly of the States, and such other public officers or persons as the National Assembly may by law prescribe shall not maintain or operate a bank account in any country outside Nigeria.

- Prohibition against accepting any gifts or benefits - (1) a public officer shall not ask for or accept property or benefits of any kind for himself or any other person on account of anything done or omitted to be done by him in the discharge of his duties. (2) For the purposes of sub-paragraph (1) of this paragraph, the receipt by a public officer of any gifts or benefits from commercial firms, business enterprises or persons who have contracts with government shall be presumed to have been received in contravention of the said subparagraph unless the contrary is proved.

- Restriction on Loans, Gifts or Benefits to certain Public Officers - The President or Vice-President, Governor or Deputy Governor, Minister of the Government of the Federation or Commissioner of the Government of the State, or any other public officer who holds the office of a Permanent Secretary or 
head of any public corporation, university, or other parastatal organization shall not accept: (a) a loan, except from government or its agencies, a bank, building society, mortgage institution or other financial institutions recognized by law, and (b) any benefit of whatever nature from any company, contractor; or businessman, or the nominee or agent of such person; provided that the head of a public corporation or of a university or other parastatal organization may, subject to the rules and regulations of the body, accept a loan from such body.

- Declaration of Assets - Subject to the provisions of this Constitution, every public officer shall within three months after the coming into force of this Code of Conduct or immediately after taking office and thereafter (a) at the end of every four years; and (b) at the end of the term of office; submit to the Code of Conduct Bureau a written declaration of all his properties, assets and liabilities and those of his unmarried children under the age of 18 years. Any statement in such declaration that is found to be false by any authority or person authorized in that behalf to verify it shall be deemed to be a breach of this Code. Any property or assets acquired by a public officer after any declaration required under this Constitution and which is not fairly attributable to income, gift or loan approved by this Code shall be deemed to have been acquired in breach of this Code unless the contrary is proved.

- $\quad$ Agents and Nominees - A public officer who does any act prohibited by this Code through a nominee, trustee or other agent shall be deemed ipso facto to have committed a breach of this Code.

The 1988 public service reforms encapsulated in the Civil Service Reorganization Decree No 43 of 1988 had long introduced the audit alarm and other preventive ethical principles including whistle-blowing in the public service and new procedures for the processing of funds. There have been frequent administrative reforms since colonial times, making one change or another to ensure effective, transparent and accountable public service (Olaopa, 2008; Ikeanyibe, 2010; Anazodo, Okoye \& Chukwuemeka, 2012).

More recently, Nigeria was among the first countries in Africa to introduce public procurement and fiscal responsibility reforms, from 2003 to 2007, in accordance with the agreement of the New Partnership for Africa's Development (NEPAD) and the Group of 8 richest countries of the world, to work to enthrone good governance in Africa. The country has various institutions (the police included) that fight corruption. The Independent Corrupt Practices and Other Related Offences Commission (ICPC) was inaugurated in 2000 to receive complaints, investigate and prosecute offenders, review and modify the systems and procedures of public bodies as well as to educate the public and foster their support in combating corruption. The Economic and Financial Crimes Commission (EFCC) was established in 2004 through the Economic and Financial Crimes Establishment Act (2004). The Act empowers the EFCC to prevent, investigate, prosecute and penalize economic and financial crimes.

In the drive towards these accountability and transparency measures and anti-corruption reform efforts, the country in 2003 voluntarily signed the global Extractive Industries Transparency Initiative (EITI) as part of the National 
Economic Empowerment and Development Strategy (NEEDS) comprehensive socio-economic reforms. The country began the process of legal enactment to back the domiciliation of the initiative, and in 2007, a specific law (the Nigeria Extractive Industries Transparency Initiative, NEITI) was enacted making Nigeria the first country in the global EITI to support implementation with legislation (NEITI, 2016). Again, the Nigeria National Assembly passed the Freedom of Information Act in 2011 to make public records and information more freely available, provide for public access to public records and information, protect public records and information to the extent consistent with the public interest and the protection of personal privacy, and to protect serving public officers from adverse consequences of disclosing certain kinds of official information without authorization and establish procedures for the achievement of those purposes and for related matters. A key objective of the act is to enhance public scrutiny of public sector operations. For instance, Section 2 (3) of the act makes provision for what every governmental institution should publish. These include materials containing information relating to any grant or contract made by or between the institution and another public institution or private organization, a description of the organization and responsibilities of the institution including details of the programmes and functions of each division, branch and department of the institution, and information relating to the receipt or expenditure of public or other funds of the institution.

In spite of the long institutionalisation and legislation of these codes, establishment of multiple corruption fighting agencies and other control measures, the rising rate or persistent high level corruption and fraud in the public sector shows that these efforts have had little impact in the prevention, detection and prosecution of corrupt public officials. Contract inflation is a permanent feature of the Nigerian public sector. Ownership of foreign bank accounts is common among officials. The on-going investigation of some of the high profile officials in the former President Goodluck Jonathan's administration reveals the rot in high political offices.

Yet ethical codes are legislated, and the fight against corruption is always claimed by every successive government. The administration of President Obasanjo (1999-2007) and that the current president, Buhari have had the disposition to probe some of the activities of past governments. Former President Obasanjo's administration had probed the late General Sani Abacha's regime, while President Buhari is currently investigating some activities of former President Goodluck Jonathan's administration. However, to limit the probe of past governments to only these two bespeaks of vindictiveness and vengeance, which supports the view that the anti-corruption fight is merely political and only directed against enemies and opponents. This is because there were clear issues of highly corrupt practices that took place in other administrations such as that of General Ibrahim Badamasi Babangida (1985 to 1993), General Abdulsalami Abubakar (1998 to 1999) and former President Olusegun Obasanjo (1999 to 2007) that are not being called to question. For instance, Nigerians had, since the Gulf War of 1991, asked questions about the oil windfall of USD12.4 billion that was not accounted for during General Babangida's administration (Oladimeji, 2016a). During the former President 
Obasanjo's administration, Nigeria's Corruption Perception Index (CPI) reached an all-time high (152 of 159) in 2005 (Transparency International, 2016). It was during his administration that the popular exchange of money through 'Ghana must go' (a common fibre-made sack) bags to get the wishes of the President including the infamous third term bid rubber-stamped by the legislature was rife. It was the era of election and campaign financing through the budgets allocated to certain Ministries like the Ministry of Works. It is therefore justified when fighting corruption is perceived as either sectional or selective of acclaimed political enemies rather than any genuine political will to deal with the monster.

High profile corruption in Nigeria is strongly influenced by the nature and ineffectiveness of the country's political and administrative control measures and the criminal justice system. There is indeed a poor connection between the reports of internal and external audits of public organizations with the activities of anti-corruption agencies. Thus, the agencies often have to rely on petitions and whistle-blowing. While this is helpful, there is also the need for official linkage to ensure effective monitoring and investigation of infractions through the internal and external audit reports of organizations. Again, the criminal justice system in the country has been found to be a significant draw-back in the fight against corruption, even by high standing political officials themselves (Lagos State Government, 2017; Channels Television, 2017). Delays in the administration of Justice, light punishment for offenders, corruption in the judiciary and outdated court administration procedures that pay much attention to court processes rather than the substance of cases are all issues in this direction.

As a matter of fact, many high profile corruption cases being prosecuted by the anti-corruption agencies have been stalled by mere legal procedures, injunctions and interlocutory appeals. In 2015, the ICPC chairman, Ekpo Nta, remarked that over 400 corruption-related cases were being prosecuted by the agency and blamed the judiciary for the draw-backs experienced in the prosecution. For EFCC, at least forty three high profile corruption cases have been stalled between 2007 and 2015 by judicial processes (Alli, 2016). Cases involving former governors of the states alone constitute 37 per cent and include: Danjuma Goje (Gombe State), Jolly Nyame (Taraba State), Joshua Dariye (Plateau State), Orji Uzor Kalu (Abia state), Saminu Turaki (Jigawa), the late Audu Abubakar (Kogi), Timipreye Sylva (Bayelsa), Murtala Nyako (Adamawa), Sule Lamido (Jigawa), Adebayo Alao-Akala (Oyo), Rashidi Ladoja (Oyo), Chimaroke Nnamani (Enugu), Gbenga Daniel (Ogun), Aliyu Akwe Doma (Nasarawa), Attahiru Bafarawa (Sokoto), and Abdullahi Adamu (Nasarawa). Other high-profile cases involving political and administrative heads of government agencies or their non-official accomplices constitute about 21 per cent and include those of ex-Minister Babalola Borishade, a former Head of the Civil Service of the Federation, Steve Oronsaye, Sani Teidi Shuaibu and other pension scam suspects, Esai Dangabar and seven others over police pension fraud, Mamman Tukur and others on NGN1.2 billion oil subsidy scandal, Walter Wagbatsoma in connection with oil subsidy, Abdullahi Alao and others (NGN2.6 billion oil subsidy scam), NASAMAN Oil Services Limited for NGN4billion oil subsidy case, Chidi Adabanya (NGN2 billion obtained from Shell Petroleum Development Company) and others (Alli, 2016). 
In the face of the legal frustrations arising from the poor judicial administrative system such as unrestricted preliminary objections, trial within trial; interlocutory appeals that often reach the Supreme Court before re-commencing at the lower court depending on the outcome, re-assigning of trial judges, abuse of court process, illness of defendants, absconding of accused persons, filing of fresh charges, and jumping of court bail among others, the anti-graft agencies often resort to plea bargaining deals to settled corruption cases. A plea bargain is "a negotiated agreement between a prosecutor and a criminal defendant [who] pleads guilty to lesser offence or to one or more multiple charges in exchange for some concession by the prosecutor, usually a more lenient sentence or a dismissal of the other charges" (Garner, 2004, p. 1189). Often the anti-corruption agencies do not have sufficient funds to prosecute these cases while the accused usually deploy their enormous stolen financial resources to truncate the course of justice.

The ICPC boss revealed that over 90 per cent of the agency's budget is used for prosecution instead of the ideal situation where at least 60 percent should be used on prevention strategies (Daniel \& Umoru, 2015). In the face of such constraints, the anti-graft agencies have had to strike a plea bargain with corrupt individuals to return part of their loot for their release. Some typical cases settled in this manner include: a one-time Chief of Air Staff arraigned with 10 others by EFCC on 26 count charges bordering on conspiracy, stealing, fraud and money laundering of a total of NGN22.8 billion (Anaba, 2016); former Acting Director General of Nigeria Maritime Administration and Safety Agency, Haruna Jauro for an alleged fraud of NGN304.1million (Ships and Ports, 2016); a former governor of Edo State, Lucky Igbinedion for various fraud and unethical financial crimes amounting to 191 count charges (Ikhide, 2008); a former Inspector General of Police, Tafa Balogun accused of NGN17 billion in 2005; and a former governor of Enugu State, Chief Chimaroke Nnamani accused of NGN5billion fraud and embezzlement of the state's fund (Oladimeji, 2016b). Invariably, once an accused public official feels he could return part of his loot to be free from punishment, he negotiated that option, otherwise spanners were effortlessly thrown into the works of the prosecution to delay or evade justice. Criminal cases bordering on huge financial crimes by public officials that should receive maximum punishment to discourage potential offenders have been reduced to civil cases that could be settled out of court through plea bargain, while allowing looters to seek and occupy other political positions shamelessly.

While we allow the legal experts to debate the usefulness of the plea bargain, it is not difficult to see that the system does not support a strict sanction or disciplinary approach to administrative ethics and will not likely prevent unethical behaviour since potential looters are given a benign option in corruption cases. Similarly, the judicial system that makes it difficult to convict offenders or mete out light punishment for weighty offences does not support an effective control and preventive approach. The failure of the Nigerian criminal justice system to effectively and severely punish the erring rich and mighty is infamous (Oladimeji, 2016b), and therefore does not show much political commitment to deal with unethical practices among the high public officials. A major incentive to corruption in Nigeria is the sacred cow treatment given to the high profile looters of public funds. 
Even in the present administration (of President Buhari) that claims that the fight against corruption is a priority, most Nigerians are not impressed with the way allegations against some members of the cabinet are being handled. For instance, the Nigerian Senate called for the removal and prosecution of the Secretary to the Federal Government (SGF), Babachir Lawal, who was alleged to have breached the country's contract award law. His company, Global Vision Ltd., was one of the companies indicted for allegedly benefiting from inflated and phantom contracts - or ones not executed at all. The contracts were awarded by the Presidential Initiative on the North East (Adebayo \& Tukur, 2016). Similarly, the appointment of the present Chairman of EFCC was not confirmed by the Senate based on an unfavourable report regarding sound ethical status by the Department of State Services (DSS), (Umoru \& Erunke, 2016). President Buhari had written back to the Senate alleging an unfair hearing and procedural error in the Senate report. While it is not fair that an individual should be punished for an offence he or she has not committed, it is more supportive of transparency and public trust in a government that suspected or accused individuals should resign or be relieved of their public office until they prove themselves otherwise. This is more crucial in a system where corruption has become a way of life and the public trust in the commitment of political leaders to deal with it is wavering.

Despite the fact that the country has emphasized the legislative approach by legislating every relevant ethical code, she has not shown a strong sanction approach in dealing with her ethical challenge. Thus, the multiple laws against unethical financial practices fail to serve the purpose securing compliance. This is because political and administrative controls are loose and the reality is that the country treats unethical behaviour with kid gloves, especially among the high political officials. Effective political and administrative control should support corruption prevention efforts by monitoring the management of public resources, detecting and signaling individual deficiencies and systemic weaknesses (OECD, 2000). As it is, the anti-graft war in Nigeria is rather reactive and cosmetic than preventive and sanction driven.

\section{Concluding Remarks}

Being consistently ranked by Transparency International among the most corrupt nations in the world, it is clear that the Nigerian ethical climate is very conducive to corruption. It therefore requires more of the compliance-based ethical system. The compliance-based approach is more appropriate to situations in which unethical behaviour is rampant and will be difficult to change, while the integrity-based approach appears more appropriate to situations in which there is a strong shared sense of values, and a higher degree of homogeneity (UNDP, 2007). Apparently, Nigeria gives the impression of using the disciplinary or sanctions approach. While efforts are made to establish laws criminalizing direct and indirect actions that lead to corruption, and sign international conventions to fight corrupt practices, the study shows that the criminal justice system treats corruption with kid gloves and provides support for high public officials to be senselessly corrupt rather than work to prevent it. Special attention has not been paid to officials in 
positions that are particularly susceptible to corruption. Creating a disciplinary ethical climate cannot be complete without strong enforcement and consequential outcomes that are sufficient to discourage potential offenders.

Thus, as far as the punishment for corrupt conducts is light and ample loopholes exist for suspects to manipulate the judicial system, citizens will continue to be attracted to government positions to get rich and indeed, as is usually the case, one will be considered foolish and stupid by his people to remain poor after holding an exalted public office. In this kind of ethical environment, it is obvious that the political will and even the psychological disposition of officials to do what is universally acceptable or to rely more on the value approach to do what is right may not produce significant results. This is the reason why better pay for the higher political and career officials has not been significant in reducing unethical conduct among them. The divergence in the level of corruption observed among the high profile public officials and the low ones lies in the effectiveness of political and administrative control measures. The low level employees are subjected to a series of administrative controls exercised by the hierarchy of their institutions; but the high level political and administrative officials have little control resulting from lack of transparency and openness in government, weak civil society actions and ineffective political leadership and will.

Subjecting politicians and high level career administrators to greater societal pressures through more open and transparent measures including the use of open bidding approaches for government contracts, exploiting and strengthening the whistle-blowing policy recently introduced by the Federal Ministry of Finance, could help to strengthen the control system. There is also need to consider enacting a law that could establish a separate system of courts to handle corruption cases, recognize lifelines in handling and dispensing the cases and significantly reviewing the punishments, including death sentences for corrupt acts involving some benchmark monetary value. It is perhaps thanks to the severity of punishment and a very strict attitude towards corruption and the Chinese criminal justice system that that country and many others in Asia as well have been doing a very good job in preventing and punishing corruption (Yunhai, 2005).

\section{REFERENCES}

1. Adebayo, H. \& Tukur, S. (2016). Nigerian Senate Calls for Removal, Prosecution of SGF Babachir Lawal. Premium Times. Available at: http://www.premiumtimesng.com/news/ headlines/217921-breaking-nigerian-senate-calls-removal-prosecution-sgf-babachir-lawal. html (accessed: 18 February, 2017).

2. Adedokun, N. (2016). Why the War Against Corruption May Fail. Punch. Available at: http:// punchng.com/war-corruption-may-fail/ (accessed: 27 February, 2017). 
3. Adejokun, S. (n.d.). How 17,474 Political Officers Earn N1.1TR Annually. Economic Confidential: NEXIM. Available at: http://economicconfidential.com/2015/07/how-17474-politicalofficers-earn-n1-1tr-annually/ (accessed: 26 January, 2017).

4. Alli, Y. (2016). Anti-Graft War: Goje, Nyame, Nnamani, Ladoja, Borishade, 38 Other HighProfile Cases Held Up, Says EFCC. The Nation. Available at: http://thenationonlineng.net/ anti-graft-war-goje-nyame-nnamani-ladoja-borishade-38-high-profile-cases-held-says-efcc/ (accessed: 23 February, 2017).

5. Anaba, I. (2016.) Amosu in Plea Bargain with EFCC. Vanguard. Available at: http://www. vanguardngr.com/2016/10/amosu-plea-bargain-efcc/ (accessed: 18 February, 2017).

6. Anazodo, R.O., Okoye, J.C. \& Chukwuemeka, E.O. (2012). Civil service reforms in Nigeria: The Journey So Far in Service Delivery. Journal of Political Studies, vol. 19, no 2, pp. 1-19.

7. Anello, E. (2006). Ethical Infrastructure for Good Governance in the Public Pharmaceutical Sector. Geneva, Switzerland: World Health Organization.

8. Asobie, A. (2001). Ethics and university administration. In: Olojede I. and Fajonyomi, S.O. (eds). Ethics and Public Accountability in Nigeria. Lagos: A-Triad Associates, pp. 214-246.

9. Butts, J.B. \& Rich, K.L. (2008). Nursing Ethics: Across the Curriculum and into Practice. $2^{\text {rd }}$ ed. (non-edited book). Sundbury, M.A, USA: Jones and Bartlett Learning, pp. 119-151.

10. Channels Television (2017). Osinbajo Calls for Reform of Criminal Justice System. Live TV Programs. Available at: https://www.channelstv.com/2017/02/03/osinbajo-calls-reformcriminal-justice-system (accessed: 23 February, 2017).

11. Cooper, T.L. (1987). Hierarchy, Virtue, and the Practice of Public Administration: A Perspective for Normative Ethics. Public Administration Review, July/August, pp. 320-328.

12. Garofalo, C., Geuras, D., Lynch, T.D. \& Lynch, C.E. (2001). Applying Virtue Ethics to the Challenge of Corruption. The Innovation Journal: The Public Sector Innovation Journal, vol. 6, no 2, pp. 1-13.

13. Geuras, D. \& Garofalo, C. (2011). Practical Ethics in Public Administration. Virginia: Management Concepts.

14. Daniel, S. \& Umoru, H. (2015). Corruption: Over 400 Cases in Courts - ICPC. Vanguard. Available at: http://www.vanguardngr.com/2015/12/corruption-over-400-cases-in-courtsicpc/ (accessed: 21 February, 2017).

15. Demmke, C. \& Moilanen, S.T. (2011). Effectiveness of Good Governance and Ethics in Central Administration: Evaluating Reform Outcomes in the Context of the Financial Crisis. Study for the 57th Meeting of the Directors General responsible for Public Services in EU Member States and European Commission, European Institute of Public Administration. Available at: https://www.integriteitoverheid.nl/fileadmin/.../Effectiveness_of_Public-service_Ethics_ and_Good_Governance_in_the_Central_Administr... (accessed: 14 December, 2016).

16. Denhardt, K. (n.d.). Public Administration and Public Policy. Vol. II - Ethics in Public Organizations. Encyclopedia of Life Support Systems. Available at: http://docplayer.net/5915448Public-administration-and-public-policy-vol-ii-ethics-in-public-organizations-kathryn-gdenhardt.html (accessed: 17 December, 2016).

17. Dmochowski, M. Jurczuk, A. \& Szczepankowski, R. (n.d.). Ethics in Public Administration. Available at: http://www.wsap.edu.pl/pub/publikacje/Ethics\%20in\%20Public\%20Administration\%20-\%20eng..pdf (accessed: 16 December, 2016).

18. Dobre, O.I. (2013). Employee Motivation and Organizational Performance. Review of Applied Socio- Economic Research, vol. 5, no 1, pp. 53-60. 
19. Egbule, R.O. (2015). Disparities in Pay in the Public Service. A Paper Delivered at the Retreat of the Steering Committee on Reforms. Available at: http://bpsr.gov.ng/index.php/news/126submission-of-expression-of-interest-eoi?fontstyle=f-smaller (accessed: 25 February, 2017).

20. Frankena, W.K. (1973). Ethics. Englewood.

21. Cliffs, N.J. (2011). Prentice-Hall Freedom of Information Act 2011 Laws of the Federation of Nigeria. Available at: https://www.cbn.gov.ng/FOI/Freedom\%20Of\%20Information\%20Act. pd (accessed: 16 February, 2017).

22. Garner, B.A. (2004). Black's Law Dictionary (8th ed.). Minnesota: Thompson Web Publishers.

23. Independent Corrupt Practices and Other Related Offences Commission, ICPC. Available at: http://icpc.gov.ng/?doing_wp_cron=1487229280.2933979034423828125000 (accessed: 16 February, 2017).

24. Ikeanyibe O.M. (2010). Reforms and public service indigenization in Nigeria (1960-2010). The Constitution, vol. 10, no 3, pp. 14-48.

25. Ikhide, R. (2008). EFCC, Igbinedion and Plea Bargaining. FocusNigeria.com. Available at: http://www.focusnigeria.com/efcc.htm (accessed: 24 August, 2018).

26. Lagos State Government (2012). Justice Reform: Osinbajo Recommends Day-To-Day Trials, Heavy Punishment for Delays. Lagos State Government: Centre of excellence Website. Available at: http://lagosstate.gov.ng/blog/2017/01/30/justice-reform-osinbajo-recommends-dayto-day-trials-heavy-punishment-for-delays/ (accessed: 23 February, 2017).

27. Lynch, D. T. \& Lynch, C. E. (2006). Aristotle, MacIntyre and Virtue Ethics. Public Administration and Public Policy, no 116, pp. 55-74.

28. Makrydemetres, A. (2002). Dealing with Ethical Dilemmas in Public Administration: The 'ALIR' Imperatives of Ethical Reasoning. International Review of Administrative Sciences, vol. 68, no 2, June, pp. 251-266.

29. Martin, K. \& Cullen, J. (2006). Continuities and Extensions of Ethical Climate Theory: A Metaanalytic Review. Journal of Business Ethics, no 69, pp. 175-194.

30. Martinez, J.M. \& Richardson, W.D. (2008). Administrative Ethics in the 21st Century. New York: Peter Lang Publishing Inc.

31. Nigeria Extractive Industries Transparency Initiative (2016). Brief history of NEITI. NEITI Website. Available at: http://www.neiti.gov.ng/index.php/aboutus/brief-history-of-neiti (accessed: 17 February, 2017).

32. OECD PUMA (2000). Trust in Government: Ethics Measures in OECD Countries. Paris, France: OECD. Available at: http://www.oecd.org/gov/ethics/Principles-on-Managing-Ethicsin-the-Public-Service.pdf (accessed: 20 December, 2016).

33. OECD (1998). Principles for Managing Ethics in the Public Service. PUMA Policy Brief, no 4. Public Management Service. Available at: http://www.oecd.org/dataoecd/60/13/1899138. pdf (accessed: 21 February, 2017).

34. Oladimeji, R. (2016a). IBB Must Face Probe of Over $\$ 12.4 b n$ Oil Windfall, Says SERAP. Available at: http://punchng.com/ibb-must-face-probe-12-4bn-oil-windfall-says-serap/ (accessed: 21 February, 2017).

35. Oladimeji, R. (2016b). Looters' plea bargain proposals to FG sparks off debate. TheNigerialawer. Available at: http://thenigerialawyer.com/looters-plea-bargain-proposal-to-fg-sparksdebate (accessed: 18 February, 2017). 
36. Olaopa, T. (2008). Theory and Practice of Public Administration and Civil Service Reforms in Nigeria. Ibadan, Nigeria: Spectrum Books Ltd.

37. O'Kelly, C. \& Dubnick, M. (2012). Moving Beyond Moralism and Instrumentalism. Paper Prepared for presentation at the 34th EGPA/IIAS Annual Conference PSG VII: Ethics and Integrity of Governance. Bergen, Norway, 5-8 September 2012.

38. Rohr, J. (1989). Ethics for Bureaucrats: An Essay on Law and Values. New York: Marcel Dekker Inc.

39. Rose-Ackerman, S. (1999). Corruption and Government: Causes, Consequences, and Reform. Cambridge, UK: Cambridge University Press.

40. The Presidency: Code of Conduct Bureau. Available at: http://www.ccb.gov.ng/index.php? option=com_content\&view=featured\&Itemid=435 (accessed: 16 February, 2017).

41. Transparency International (2016). Corruption Perceptions Index 2005. Available at: http:// www.transparency.org/research/cpi/cpi_2005 (accessed: 25 February, 2017).

42. Ships \& Ports (2016). N304m Fraud: Ex-NIMASA DG, Jauro Proposes Plea Bargain with EFCC. Available at: http://shipsandports.com.ng/n304m-fraud-ex-nimasa-dg-jauro-proposesplea-bargain-with-efcc/ (accessed: 18 February, 2017).

43. Stare, J. \& Klun, M. (2016). An Analysis of the Ethics Infrastructure and Ethical Climate in Slovenian Public Administration. The NISPAcee Journal of Public Administration and Policy, vol. IX, no 2, 147-164.

44. (UNDP (2007). Case Evidence On 'Ethics and Values in Civil Service Reforms': A UNDP Capacity Development Resource. Available at: www.undp.org/.../capacity-development/caseevidence-on-ethics-and-values-in-civil-s (accessed: 25 February, 2017).

45. Umoru, H. \& Erunke, J. (2016). Senate Rejects Magu's Nomination as EFCC Chair. Vanguard. Available at: http://www.vanguardngr.com/2016/12/senate-rejects-magus-nomination-efccchair/ (accessed: 25 February, 2017).

46. Van Rijckeghem, C. \& Weder, B. (1997). Corruption and the Rate of Temptation: Do Low Wages in the Civil Service Cause Corruption?" Washington DC, Working Paper for the International Monetary Fund.

47. Vanguard (2016). Nigeria is 'fantastically corrupt' - UK's Prime Minister, David Cameron. Available at: http://www.vanguardngr.com/2016/05/nigeria-is-fantastically-corrupt-uksprime-minister-david-cameron (accessed: 25 February, 2017).

48. Weisband, E. \& Frank, T.M. (1975). Resignation in Protest. New York: Grossman.

49. Whitley, R. (2002). Competing Capitalisms: Institutions and Economies. Cheltenham: Elgar.

50. Yunhai, W. (2005). Corruption and Anti-Corruption Policy in Today's China. Hitotsubashi Journal of Law and Politics, no 33, pp. 1-5. Available at: http://unpan1.un.org/intradoc/ groups/public/documents/apcity/unpan047848.pdf (accessed: 25 February, 2017). 